\title{
Antiviral and virucidal potential of Origanum vulgare Linn. (oregano) extracts against Bovine alphaherpesvirus 1 (BoHV-1)
}

Potencial antiviral e virucida de extratos de Origanum vulgare Linn. (orégano) contra o Alphaherpesvírus bovino 1 (BoHV-1)

Potencial antiviral y virucida de extractos de Origanum vulgare Linn. (orégano) contra el Alfaherpesvirus bovino 1 (BoHV-1)

\begin{abstract}
The search for natural resources with antiviral potential, as an alternative to synthetic drugs, has been growing and, in this sense, oregano presents itself as a potential candidate. However, the antiviral studies with oregano are still poorly explored. BoHV-1 stands out among veterinary pathogens, for its economic impact on cattle production. In this study, the antiviral and virucidal activity of polar extracts of Origanum vulgare was evaluated against BoHV-1. Infusion (INF10), decoction (DEC), and hydroalcoholic (HAE) extracts were tested to cytotoxic and antiviral assays on MDBK cells. Cytotoxic effects were analyzed through MTT assay and the antiviral activity was expressed as a percentage of
\end{abstract}


inhibition (PI). BoHV-1 was incubated with $O$. vulgare extracts as virucidal assay. Concentrations $\leq 3.12 \mathrm{mg} / \mathrm{ml}$ (INF10) and $\leq 1.56 \mathrm{mg} / \mathrm{ml}$ (DEC/HAE) preserved the cell viability above $60 \%$, and all extracts were safe $(>96 \%)$ between 0.78 and $0.39 \mathrm{mg} / \mathrm{ml}$. Regarding the antiviral activity, pre-treatment of all extracts highlighted in comparison to the post-treatment. The pre-treatment of infusion at $2 \mathrm{mg} / \mathrm{ml}$ highlighted due to the high cell viability $(84.69 \%)$ and the elimination of the viral load. All extracts inactivated BoHV-1 from 2 hours of incubation $(20 \mathrm{mg} / \mathrm{ml})$, showing virucidal activity. These findings may be related to 4-hydroxybenzoic acid as prevalent in all extracts. These findings showed the in vitro antiviral and virucidal activity of oregano polar extracts against BoHV-1 and may be promising for the therapeutic use against herpesviruses infections.

Keywords: Alternative therapeutic; Aqueous extract; Hydroalcoholic extract; Virus; Cytotoxicity.

\title{
Resumo
}

A busca por recursos naturais com potencial antiviral, como uma alternativa aos fármacos sintéticos, tem sido crescente e, neste sentido, o orégano apresenta-se como um candidato em potencial. No entanto, estudos antivirais com orégano ainda são pouco explorados. O alphaherpesvírus bovino 1 (BoHV-1) destaca-se entre os patógenos veterinários por seu impacto econômico na pecuária. Neste estudo foi avaliada a atividade antiviral e virucida de extratos polares de Origanum vulgare contra o BoHV-1. Extratos de infusão (INF10), decocção (DEC) e hidroalcoólico (HAE) foram testados em ensaios citotóxicos e antivirais em células MDBK. Os efeitos citotóxicos foram analisados por meio de ensaio MTT e a atividade antiviral expressa em Porcentagem de Inibição (PI). O BoHV1 foi incubado com os extratos de $O$. vulgare para avaliação do potencial virucida. As concentrações de $\leq 3,12 \mathrm{mg} / \mathrm{ml}$ (INF10) e $\leq 1,56 \mathrm{mg} / \mathrm{ml}$ (DEC / HAE) preservaram a viabilidade celular acima de $60 \%$, e todos os extratos foram seguros $(>96 \%)$ entre 0,78 e $0,39 \mathrm{mg} / \mathrm{ml}$. Em relação à atividade antiviral, o pré-tratamento de todos os extratos destacou-se em comparação ao pós-tratamento. O pré-tratamento da infusão de $2 \mathrm{mg} / \mathrm{ml}$ destacou-se pela alta viabilidade celular $(84,69 \%)$ e pela eliminação da carga viral. Todos os extratos inativaram o BoHV-1 a partir de 2 horas de incubação $(20 \mathrm{mg} / \mathrm{ml})$, mostrando atividade virucida. Esses achados podem estar relacionados ao ácido 4hidroxibenzóico, prevalente em todos os extratos. Esses achados demonstram atividade antiviral e virucida in vitro de extratos polares de orégano contra BoHV-1, podendo ser promissores no uso terapêutico contra infecções por herpesvírus.

Palavras-chave: Terapia alternativa; Extrato aquoso; Extrato hidroalcoólico; Vírus; Citotoxicidade.

\begin{abstract}
Resumen
La búsqueda de recursos naturales con potencial antiviral, como alternativa a las drogas sintéticas, ha ido creciendo y, en este sentido, el orégano se presenta como un candidato potencial. Sin embargo, los estudios antivirales con orégano aún están poco explorados. El BoHV-1 se destaca entre los patógenos veterinarios por su impacto económico en la producción ganadera. En este estudio, se evaluó la actividad antiviral y virucida de extractos polares de Origanum vulgare contra BoHV-1. Se probaron extractos de infusión (INF), decocción (DEC) e hidroalcohólicos (HAE) para ensayos citotóxicos y antivirales en células MDBK. Los efectos citotóxicos se analizaron mediante el ensayo MTT y la actividad antiviral se expresó como porcentaje de inhibición (PI). Se incubó BoHV-1 con extractos de O. vulgare como ensayo virucida. Las concentraciones $\leq 3,12 \mathrm{mg} / \mathrm{ml}$ (INF) y $\leq 1,56 \mathrm{mg} / \mathrm{ml}$ (DEC / HAE) preservaron la viabilidad celular por encima del $60 \%$, y todos los extractos fueron seguros $(>96 \%)$ entre 0,78 y $0,39 \mathrm{mg} / \mathrm{ml}$. En cuanto a la actividad antiviral, se destacó el pretratamiento de todos los extractos en comparación con el postratamiento. El pretratamiento de infusión a $2 \mathrm{mg} / \mathrm{ml}$ destacó por la alta viabilidad celular $(84,69 \%)$ y la eliminación de la carga viral. Todos extractos inactivaron BoHV-1 en 2 horas de incubación $(20 \mathrm{mg} / \mathrm{ml})$, mostrando actividad virucida. Estos hallazgos pueden estar relacionados con el ácido 4-hidroxibenzoico, predominante en todos extractos. Estos hallazgos mostraron la actividad antiviral y virucida in vitro de los extractos polares de orégano contra BoHV-1 y pueden ser prometedores para el uso terapéutico contra infecciones por herpesvirus.
\end{abstract}

Palabras clave: Terapia alternativa; Extracto acuoso; Extracto hidroalcohólico; Virus; Citotoxicidad.

\section{Introduction}

Among viral pathogens of veterinary importance, members of the Herpesviridae family are characterized by their capacity to remain latent in their host over a lifetime for later spread (Roizman et al., 2013). The Bovine alphaherpesvirus 1 (BoHV-1) infections have high morbidity and cause economic losses to livestock, since treatment of those infections are unknown. These viruses mainly affect the respiratory and genital tract of male and female bovines, but reproductive damages are what stand out most, causing abortions, return to estrus, and retention of the placenta (Hage et al., 1996). After primary infection and viraemia, BoHV-1 becomes latent in the nerve ganglia. In immunosuppressed animals, a reactivation of the virus occurs leading to the appearance of clinical signs, elimination of the agent or even elimination without the presence of 
symptoms. The main control measures are the identification and elimination of infected animals and herd vaccination (Franco \& Roeche, 2007; Loi et al., 2013).

Natural or synthetic resources that can be processed or present antimicrobial activity of bioactive molecules have been a subject of intensive research involving synthetic products of plant, animal and microbial origin (Bastos et al., 2011; Santos et al., 2020; Araújo et al., 2021). The need to control viral infections caused by re-emergent and resistant pathogenic microorganisms has contributed to a gradual increase in the number of studies on products with antiviral capacity (Thakur et al., 2012). The use of natural compounds as a means of controlling or treatment for viral infections is a promising alternative to synthetic drugs, which often do not show the expected efficacy. Among some natural products that have been studied, Origanum vulgare is a versatile plant, well-known for a long time in folk medicine. For the past few decades it has been recognized for its potential therapeutic role, with diaphoretic, carminative, antispasmodic, tonic and antiseptic properties (Costa et al., 2009). Oregano aqueous extracts of facile preparation, such as infusion and decoction, are traditionally used in an empirical way all around the world, and oregano tea is broadly used in Turkey against gastrointestinal disturbances and in lowering blood cholesterol and glucose levels (Baser, 2002).

Although the plant's chemical composition depends on a number of factors, such as species, climate, altitude, and harvest time, all species of the genus Origanum are rich in various phenolic compounds, lipids and fatty acids, flavonoids and anthocyanins (Kintzios, 2002; Pereira et. al., 2020). P-coumaric acid, ferulic acid, caffeic acid, p-hydroxybenzoic acid, vanillic acid and rosmarinic acid were found especially in the species Origanum vulgare (Gerothanassis et al., 1998; Waller et al., 2018), and are responsible for the plant's various pharmacological properties when acting alone or in a synergistic manner. In spite of having antibacterial (Costa et al., 2009) and antifungal (Waller et al., 2018) activity, studies on antiviral activity of oregano are still limited, especially those on multi-resistant viruses (Blank et al., 2017; Blank et al., 2019). The main lines of research have been focused on viruses of human importance, but studies on viruses of veterinary importance have been gaining prominence (Blank et al., 2017). The activity of oregano on viral pathogens in animals, such as BoHV-1, has not yet been investigated. The present study therefore aimed to evaluate in vitro the antiviral and virucidal activity of aqueous and hydroalcoholic extracts of Origanum vulgare against BoHV-1.

\section{Methodology}

The methodology used in this study was a quali-quantitative method. According to Pereira el al. (2018), qualiquantitative approach analysis provides a better understanding of the phenomenon under study, in which numerical results obtained are used to complement the qualitative results.

The research was carried out between the years 2019 and 2020 at the Mycology, Virology and Immunology Laboratories, Faculty of Veterinary Medicine, Federal University of Pelotas.

\section{Cells, viruses and reagents}

Madin-Darby Bovine Kidney (MDBK) cells were used in this study due to their permissivity to the virus tested (BoHV-1, Los Angeles strain). Cells and viruses were obtained from our Laboratory of Virology and Immunology, Faculty of Veterinary Medicine, Federal University of Pelotas, Brazil.

For the cytotoxicity, antiviral and virucidal assays, Eagle's Minimum Essential Medium (E-MEM, Sigma-Aldrich Corp., St.Louis, MO) was used in conjunction with antibiotics - penicillin (200 UI/mL, Sigma-Aldrich, USA), streptomycin $\left(0.2 \mu \mathrm{g} / \mathrm{mL}\right.$, Vetec ${ }^{\circledR}$, Brazil), enrofloxacin $\left(10 \mathrm{mg} / \mathrm{mL}\right.$, Bayer®, Brasil) and amphotericin B $\left(0.025 \mu \mathrm{g} / \mathrm{mL}\right.$, Cristalia ${ }^{\circledR}$, Brazil $)$ - for dilution of compounds and virus, and for cell culture, E-MEM supplemented with 10\% Fetal Bovine Serum (SFB, Gibco, 
Grand Island, NY). MDBK cells were grown on 96-well polystyrene plates (KASVI®, Brazil) at a temperature of $37^{\circ} \mathrm{C}$ in a $5 \% \mathrm{CO} 2$ environment, until a monolayer at a concentration of $1 \times 10^{7} \mathrm{cells} / \mathrm{mL}$ was established.

To perform the cytotoxicity tests, MTT reagent (3-(4.5 dimethylthiazol-2yl)-2-5-diphenyl-2H-tetrazolato bromine) and dimethylsulfoxide were used, both obtained commercially from Sigma-Aldrich Corp. (St. Louis, MO).

\section{Extracts of Origanum vulgare}

Dried aerial parts of Origanum vulgare with certified quality were purchased commercially (Luar Sul@ - Indústria e Comércio de Produtos Alimentícios Ltda., Santa Cruz do Sul, RS, Brazil), and were used to prepare the different extracts. The infusion was prepared by immersing the dried plant $(10 \% \mathrm{w} / \mathrm{v})$ in boiling distilled water, remaining at room temperature for 10 min (INF10). The decoction (DEC) was obtained by immersing the plant $(10 \% \mathrm{w} / \mathrm{v})$ in distilled water at room temperature, followed by 10 minutes of boiling. Then, both aqueous extracts were filtered through MN 615 filter paper (Macherey-Nagel, Duren, Germany). The hydroalcoholic extract (HAE) was obtained from a tincture prepared by immersion of the aerial parts $(10 \% \mathrm{w} / \mathrm{v})$ in ethanol $70 \%(\mathrm{v} / \mathrm{v})$ for seven days and with daily homogenization. The preparation was then filtered with sterile gauze and concentrated by rotary evaporation under reduced pressure. The evaporated volume was replenished with distilled water.

\section{Chemical analysis}

The aqueous and hydroalcoholic extracts of Origanum vulgare were previously analyzed using LC-MS/MS (Impact HD, Bruker Daltonics, Germany). External calibration curves were used to quantitate standard phenolic compounds (caffeic acid, chlorogenic acid, syringic acid, ferulic acid, p-coumaric acid and 4-hydroxibenzoic acid) and flavonoids (luteolin, (-)epicatechin, rutin, quercetin, hesperetin), according to Waller et al. (2018).

\section{Cytotoxicity assay}

MDBK cells were grown in 96-well plates for 24 hours and then treated with different samples and concentrations of oregano. Control group cells were maintained in E-MEM without exposure to any kind of treatment. The remaining cells were exposed in quadruplicate to eight different concentrations of $O$. vulgare extracts, namely: 50, 25, 12.5, 6.25, 3.12, 1.56, 0.78, and $0.39 \mathrm{mg} / \mathrm{mL}$, for 72 hours and then submitted to MTT assay (3-(4.5 dimethylthiazol-2yl)-2-5-diphenyl-2H-tetrazolato bromine), according to Mosmann (1983). Percentages of cell viability were calculated by using the following equation: $\mathrm{CV}=$ AT/AC x 100, where AT and AC mean the absorbance in treated cells and in control cells, respectively. The cytotoxic concentrations for $50 \%$ of the cell cultures (CC50) were thus obtained.

\section{Antiviral activity assay}

Titers are expressed as 50\% of the tissue culture infective dose (TCID50). Antiviral activity was expressed in percentage of inhibition (PI) and calculated as follows:

$$
\mathrm{PI}=\left[1-\left(\frac{\text { antilog treatment }}{\text { antilog control }}\right)\right] X 100
$$

The extract concentrations for this assay were chosen from the cytotoxicity assays: INF10 (1, 2, 3 e $4 \mathrm{mg} / \mathrm{mL})$, DEC and $\operatorname{HAE}(0.5,1.0,1.5$ e $2.0 \mathrm{mg} / \mathrm{mL})$. After culture on 96-well plates, cells from two plates were exposed to the extracts (100 $\mu \mathrm{L} /$ well) for 24 hours and then infected with BoHV-1 at a MOI of 0.1 . After 72 hours of incubation, one of the plates was subjected to MTT assay and the other was subjected to a freeze-thaw cycle for determining viral titers according to the method 
of Reed and Muench (1938) in each of the concentrations of the extracts tested. This methodology characterized the preinfection treatment.

The same methodology was applied for the post-exposure treatment, but with cell pre-infection for 2 hours with BoHV-1 at a MOI of 0.1, followed by treatment with the extracts. The readings were taken in the same manner after 72 hours of incubation.

\section{Virucidal assay}

BoHV-1 was incubated with $20 \mathrm{mg} / \mathrm{ml}$ of $O$. vulgare extracts at room temperature $\left(22^{\circ} \mathrm{C}\right)$, simulating a sanitizing action in environments and fomites. After 1, 2, 4, 8 and 24h of incubation, cell suspension aliquots were subjected to viral titration according to the method of Reed and Muench (1938). The control sample consisted of virus not exposed to extracts (0h).

\section{Statistical analysis}

The analysis of variance (ANOVA) was performed, and means were compared by Tukey's test, adopting a 95\% significance as the basis for asserting differences between averages. The statistical analysis was performed with BioEstat ${ }^{\circledR}$ (version 5.3).

\section{Results}

\section{Chemical analysis}

According to the chemical analysis previously performed (Waller et al., 2018), phenolic acids and flavonoids were found in all aqueous and hydroalcoholic extracts tested, with the exception of (-) - epicatechin, which was not detected in any extract. Among the compounds evaluated, 4-hydroxybenzoic acid was highly quantified (mean values \pm standard deviation), being the prevalent compound for all $o$. vulgare extracts: INF10 $(120.44 \pm 1.5 \mu \mathrm{g} / \mathrm{g})$, DEC $(144.98 \pm 16.24 \mu \mathrm{g} / \mathrm{g})$ and HAE $(160.61 \pm 0 \mu \mathrm{g} / \mathrm{g})$, followed by syringe acid and caffeic acid for the aqueous extracts, whereas the hydroalcoholic extract showed a higher amount of caffeic acid followed by syringic acid. Among the flavonoids, luteolin was identified only in the hydroalcoholic extract of $O$. vulgare tested, being absent in the aqueous extracts (Waller et al., 2018).

\section{Cytotoxicity assays}

Regarding the viability of MDBK cell lines exposed to oregano extracts (Figure 1), all of the extracts preserved the cell viability above $60 \%$ at concentrations up to $1.56 \mathrm{mg} / \mathrm{ml}$ (DEC and HAE) and up to $3.12 \mathrm{mg} / \mathrm{ml}$ (INF). The $\mathrm{CC}_{50}$ were 3.25 $\mathrm{mg} / \mathrm{ml}$ (INF), $1.6 \mathrm{mg} / \mathrm{ml}$ (DEC) and $1.3 \mathrm{mg} / \mathrm{ml}$ (HAE). Additionally, all extracts were safe between 0.78 and $0.39 \mathrm{mg} / \mathrm{ml}$, preserving more than $96 \%$ of the MDBK cells. 
Figure 1. In vitro cell viability of Madin-Darby Bovine Kidney (MDBK) cell lines exposed to infusion, decoction, and hydroalcoholic extracts of Origanum vulgare Linn. (mg/ml).

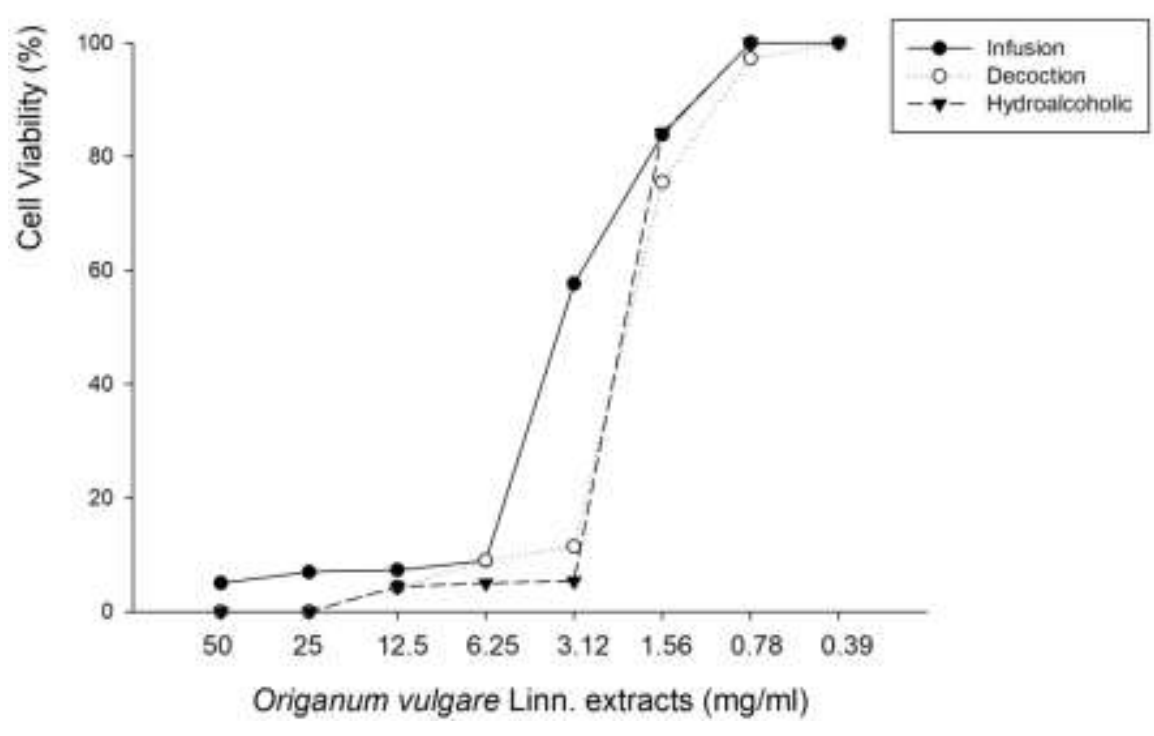

Source: Authors (2020).

\section{Antiviral activity assays}

Analyzing the antiviral activity (Figure 2), the pre-treatment protected the MDBK cells against the BoHV-1 cytopathic effect (CPE) in comparison to the post-treatment, and the pre-treatment with infusion was highlighted by its antiviral activity. Among all the tested polar extracts, a concentration of $2 \mathrm{mg} / \mathrm{ml}$ for INF10 in pre-infection treatment presented the best antiviral activity against BoHV-1, with PI $=100 \%$ and cell viability $(\mathrm{CV})$ close to the control cells (84.69\%). The lowest concentration, although with PI $=99.4 \%$, showed only $52.39 \%$ of $\mathrm{CV}$. The highest concentrations ( 3 and $4 \mathrm{mg} / \mathrm{ml}$ ) also showed PI $=100 \%$, but the CV began to be affected by the toxicity of the extract itself. In the post-infection treatment, at a $2 \mathrm{mg} / \mathrm{ml}$ concentration, we had PI $=43.8 \%$ and $\mathrm{CV}=33.68 \%$, and at a concentration of $3 \mathrm{mg} / \mathrm{ml}, \mathrm{PI}=100 \%$ and $\mathrm{CV}=65.87 \%$.

Considering the antiviral activity of $O$. vulgare decoction, it is possible to observe that the pre-infection treatment presented more effective results, since at a concentration of $1 \mathrm{mg} / \mathrm{ml}$ values obtained were $\mathrm{PI}=99.9 \%$ and $\mathrm{CV}=59.7 \%$, and at $1.5 \mathrm{mg} / \mathrm{ml}$ eliminated the viral load ( $\mathrm{PI}=100 \%)$, but showed lower cell viability ( $\mathrm{CV}=48.2 \%)$. In the post-infection treatment, a concentration of $1 \mathrm{mg} / \mathrm{ml}$ showed PI $=82.2 \%$ and $\mathrm{CV}=58.22 \%$, and at $1.5 \mathrm{mg} / \mathrm{ml} \mathrm{PI}=99.4 \%$ and $\mathrm{CV}=36.8 \%$. Even at the highest concentration tested $(2 \mathrm{mg} / \mathrm{ml}) \mathrm{PI}=100 \%$ was not obtained in the post-infection treatment.

The antiviral activity for HAE of $O$. vulgare in pre-infection treatment showed $\mathrm{PI}=99 \%, \mathrm{CV}=69.32 \%$ at a concentration of $1 \mathrm{mg} / \mathrm{ml}$, and $\mathrm{PI}=99.99 \%, \mathrm{CV}=59.79 \%$ at $1.5 \mathrm{mg} / \mathrm{ml}$, that highlighted as antiviral, reducing the viral load $\left(\mathrm{TCID}_{50}\right)$ from $10^{5.75}$ to $10^{0.5}$. In post-infection treatment, there was no viral inhibition at a concentration of $1 \mathrm{mg} / \mathrm{ml}$, although cell viability had shown $\mathrm{CV}=72.63 \%$. At a concentration of $1.5 \mathrm{mg} / \mathrm{ml}$, values obtained were $\mathrm{PI}=99 \%$ e CV=50.65\%. 
Figure 2. Antiviral activity of polar extracts of Origanum vulgare Linn. (infusion, decoction and hydroalcoholic extract; $\mathrm{mg} / \mathrm{ml}$ ) in the pre-treatment and post-treatment against bovine alphaherpesvirus type 1 (BoHV-1) and expressed by the cell viability $(\%)$ and viral $\operatorname{load}(\log 10)$ after 72 hours of incubation.
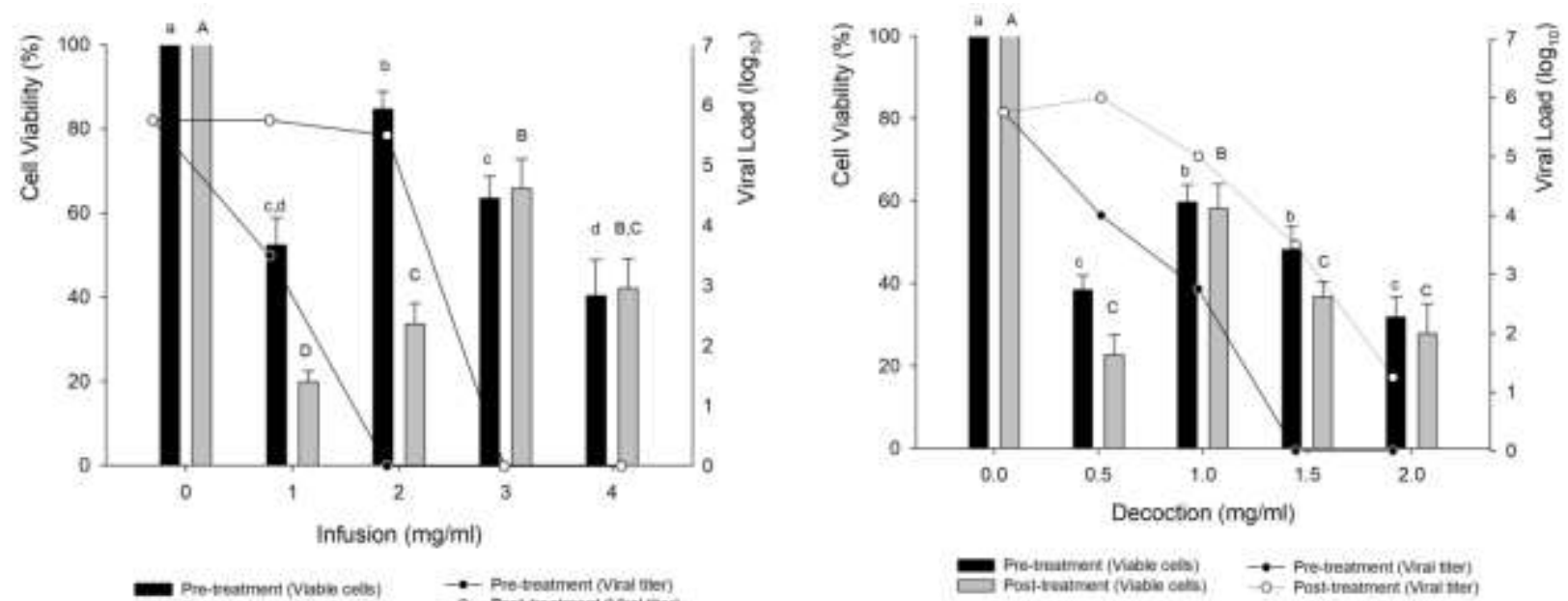

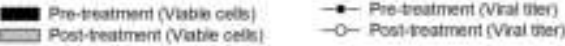

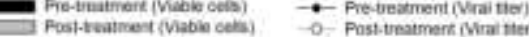

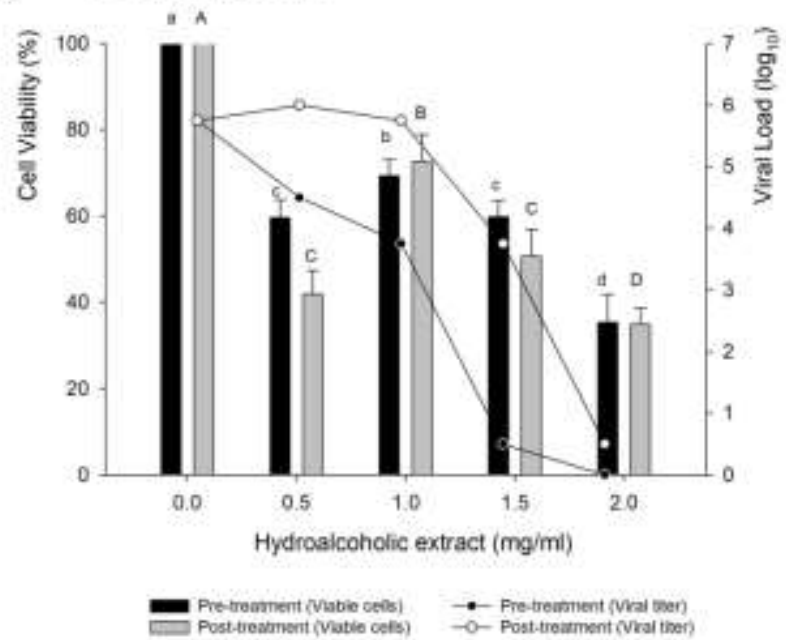

Source: Authors (2020).

\section{Virucidal activity assay}

In the virucidal assay (Figure 3), the positive control (viral control) showed a drop in viral load in the titration of $10^{5.75}$ to $10^{4.25} \mathrm{TCID}_{50 / 25} \mu \mathrm{l}$ during the 24 hours of the experiment. Interestingly, all polar extracts at a concentration of $20 \mathrm{mg} / \mathrm{ml}$ inactivated the BoHV-1 suspension after 2 hours of incubation at $22{ }^{\circ} \mathrm{C}$, showing the oregano potential virucidal activity against this virus. 
Figure 3. Virucidal activity of polar extracts of Origanum vulgare Linn. (infusion, decoction, and hydroalcoholic extract) at 20 $\mathrm{mg} / \mathrm{ml}$ after 24 hours of incubation $\left(22^{\circ} \mathrm{C}\right)$ against bovine alphaherpesvirus $1(\mathrm{BoHV}-1)$.

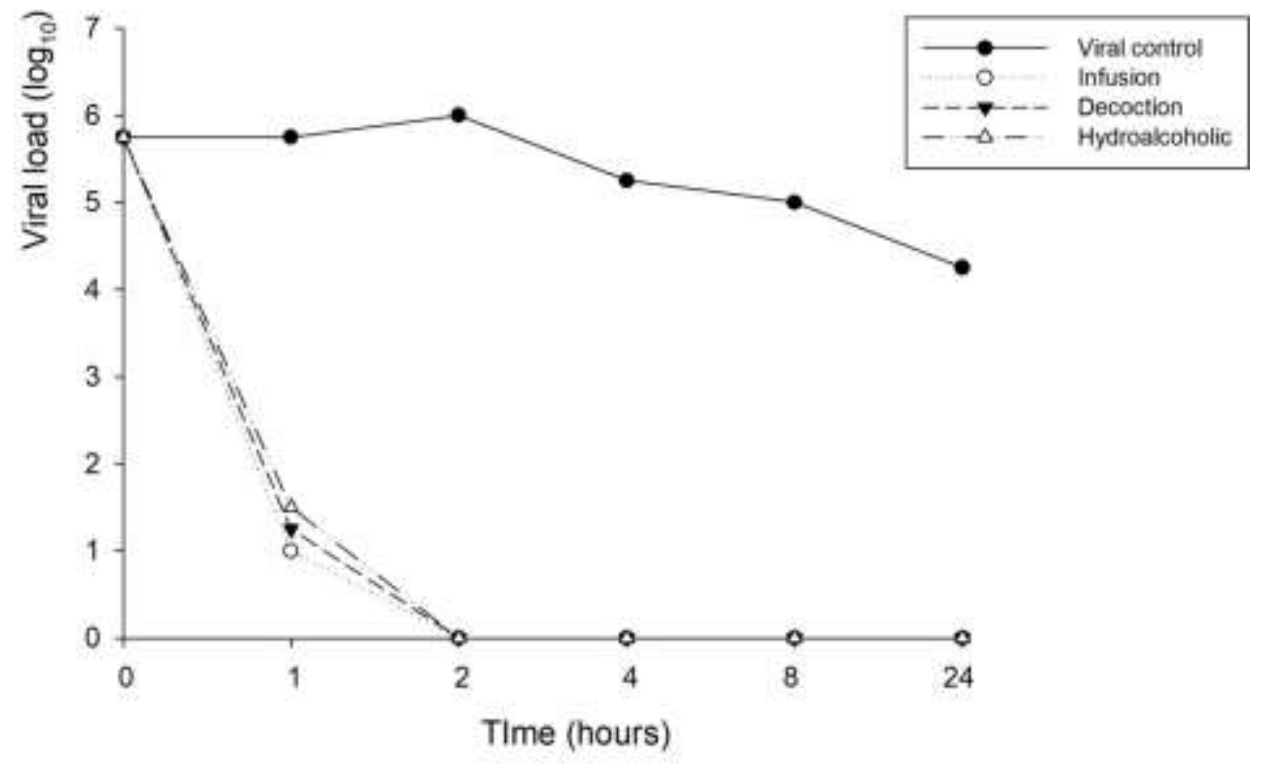

Source: Authors (2020).

\section{Discussion}

Culinary uses of oregano have been reported for a long time (Vanaclocha et al., 2003; Longe, 2005). Indeed, such use is considered safe (FDA) with no recommendations issued by worldwide authorities. With regard to its medicinal applications, infusions and decoctions are, in fact, of facile preparation. They can be used in a wide range of medical conditions by most people, much more safely than essential oils, which may cause adverse effects in low concentrations (EFSA, 2010). For the European Food Safe Authority (EFSA, 2010), however, the indiscriminate use of oregano is due to a lack of in-depth studies either providing scientific evidence of pharmacological efficacy or showing absence of adverse effects instead.

There are several studies on $O$. vulgare showing antiparasitic (Castro et al., 2013) and antimicrobial properties of its aqueous (Kandasamy et al., 2017; Waller et al., 2018) and alcoholic (Al-Jaboury, 2015; Coccimiglio et al., 2016) extracts and essential oils (Kalemba \& Kunicka, 2003; Burt, 2006; Pauli, 2006; Palmeira et al., 2009; Orhan et al., 2012). However, due to their facile preparation, aqueous extracts, such as infusion and decoction, are commonly used for a wide range of purposes (food or therapy) without their actual activities and/or mechanisms of action being known (Martins et al., 2014). The biological effects of those extracts should be better understood to allow for not only a safer popular use but also a wider applicability in the pharmaceutical industry.

Several scientific studies report on the composition of different forms of $O$. vulgare extraction from different geographic regions. None of these studies, however, reports the same phenolic composition, but present similarities among components (Rodriguez-Meizoso et al., 2006; Skoula et al., 2008; Grevsen et al., 2009; Hossain et al., 2010; Shen et al., 2010; Miron et al., 2011; Agiomyrgianaki \& Dais, 2012; Martins et al., 2014; Waller et al., 2018). Zhang et al. (2014) tested a number of phenolic constituents of oregano for antiviral activity, including six new compounds identified. However, most constituents have not presented antiviral effects against Respiratory Syncytial Virus (RSV) and Herpes Simplex Virus type 1 (HSV-1). Only apigenin presented a discrete effect against RSV. Only one of the new compounds and 2,5-hydroxybenzoic acid presented a weak action against HSV-1.

Other compounds of interest, such as parabens, 4-hydroxybenzoic acid esterification products, affect the cytoplasmic membrane potential and permeability, and may also influence the electron transport system. They have antimicrobial effect, 
and it has been suggested that their mechanism of action is related to the inhibition of DNA and RNA synthesis and enzymes such as ATPase and phosphotransferase (Kosová et al., 2015). The 4-hydroxybenzoic acid was the phenolic component found in most of the three oregano extracts evaluated in our study, as previously reported (Waller et al., 2018) and that agrees with the aqueous extracts tested by other studies (Blank et al., 2016; Martins et al., 2014). This phenolic acid may be responsible for the cytotoxic and antiviral effects observed in our experiments, since the virus studied (BoHV-1) has DNA as genetic material and has an envelope similar to the plasma membrane of cells. Although we did not test the antiviral and virucidal activities of the chemical compounds found, it seems that the predominance 4-hydroxybenzoic acid in all polar extracts may be related to the activity against BoHV-1 since all of them inhibited and eliminated this virus species.

Early in the 80's, in a study by Kaul et al. (1985), the antiviral effects of flavonoids including quercetin and hesperetin, which were also found in the extracts we evaluated (Waller et al., 2018), presented antiviral activity. Quercetin $\left(200 \mu \mathrm{M}, 2 \mathrm{~h}, 37^{\circ} \mathrm{C}\right)$ reduced the infectivity of the respiratory syncytial virus $(97 \%)$, poliovirus type $1(90 \%), \mathrm{HSV}-1(76 \%)$ and parainfluenza virus type $3(80 \%)$. Similarly, hesperetin $\left(200 \mu \mathrm{M}, 2 \mathrm{~h}, 37^{\circ} \mathrm{C}\right)$ interfered with the viral multiplication process, reducing the intracellular replication of HSV-1 (64\%) and poliovirus-1 (53\%). Despite this, it has not reduced the ability of viruses to infect cells, as it does not act on the cell membrane receptors. These two compounds may have been responsible for our findings, but we do not rule out the possibility that other compounds present in the extracts may also act as antiviral agents in an isolated or synergistic manner, such as the 4-hydroxybenzoic acid, as previously mentioned.

Previous studies using different extracts of $O$. vulgare have already shown their antibacterial (Carezzano et al., 2017; Szczepanik et al., 2018; Wijesundara \& Rupasinghe, 2018) and antifungal (Waller et al., 2016; Ksouri et al., 2017; Brondani et al., 2018; Waller et al., 2018) ability. However, antiviral and/or virucidal activity assays are still limited in the literature. The results of Blank et al. (2017) provide evidence that the ethanolic extract of oregano has anti-EAV (Equine Arteritis Virus) effect. Among the main compounds evaluated, caffeic acid, p-coumaric acid, carnosic acid, campferol and, mainly, quercetin, contributed to the antiviral activity of the extract. These authors (Blank et al., 2017) concluded that the ethanolic extract of oregano may represent a good prototype for the development of a new antiviral agent, and it is a promising alternative against arterivirus infections. Orhan et al. (2012) developed a study analyzing the antimicrobial (and antiviral) activity of several essential oils, including $O$. vulgare and isolated chemical components. These authors reported that they had obtained 0.2 $\mu \mathrm{g} / \mathrm{mL}$ of $O$. vulgare essential oil against Herpes Simplex Virus type 1 (HSV-1) and $0.4 \mu \mathrm{g} / \mathrm{mL}$ against Parainfluenza type 3 (PI-3) as the minimum inhibitory concentration (MIC) of cytopathic effect. These data reflect the antiviral activity of the plant extract, since those are two viruses with distinct characteristics, the first one (HSV-1) is a DNA virus, and the second one (PI3 ) is an RNA virus. These findings suggest that distinct mechanisms of action may be associated with the antiviral effect of the extracts and/or its isolated compounds.

This fact is most evident in a bibliographic review by Bekut et al. (2018) reporting the activity of $O$. vulgare essential oil against murine norovirus and against yellow fever virus, both RNA viruses, but the first one non-enveloped and the second one enveloped. These authors also report the antiviral activity of aqueous extracts of $O$. vulgare against the Human Immunodeficiency Virus (HIV), which draws attention to the worldwide importance of that virus in human health, as well as to the fact that aqueous extracts have their constituents in less number and concentration, as reported in several chromatographic studies of Lamiaceae family plant extracts (Rodriguez-Meizoso et al., 2006; Skoula et al., 2008; Grevsen et al., 2009; Hossain et al., 2010; Shen et al., 2010; Miron et al., 2011; Agiomyrgianaki \& Dais, 2012; Martins et al., 2014; Waller et al., 2018).

In the studies conducted by Elizaquível et al. (2013), oregano oil (2\%) was able to reduce the viral titer of murine norovirus and feline calicivirus (both unenveloped) at $1.62 \log 10$ and $3.75 \log 10$, respectively, after incubation at $37{ }^{\circ} \mathrm{C}$. However, there was no significant reduction in titers with incubation at $4{ }^{\circ} \mathrm{C}$, suggesting a temperature-dependent antiviral effect. Koch et al. (2008) and Astani et al. (2011) report that pre-treatment of HSV-1 and HSV-2 with different essential oils 
inhibited infectivity, but pre-treatment of the cells did not demonstrate the same effect. The authors' conclusion regarding the mechanism of action of essential oils is based on the direct binding of the components to the viral particles, which impairs viral adsorption to the host cell. These results differ from those found in our study because in the evaluations of the three $O$. vulgare extracts pre-treatment of host cells resulted in better antiviral activity against BoHV-1. However, it is worth noting that our study aimed to evaluate the effects of two aqueous extracts (infusion and decoction) and one hydroalcoholic extract, while those authors (Koch et al., 2008; Astani et al., 2011) studied essential oils.

There are studies in the scientific literature that suggest a mechanism of action of oregano against viruses. Using transmission electron microscopy (TEM), Siddiqui et al. (1996) suggest envelope dissolution of HSV-1 and Newcastle disease virus after exposure to oregano. However, the authors have not established a relation between the binding of the antimicrobial agent to the viral envelope and the envelope dissolution itself. Using oregano essential oil (4\%), Gilling et al. (2014) reported a reduction in the murine norovirus titer. After 1 hour of exposure the titer reduced by $0.98 \pm 0.17 \log 10$, and after 6 hours it reduced by $1.10 \pm 0.12 \log 10$. These authors also performed a similar experiment using carvacrol, the major constituent of the essential oil identified by them. After 1 hour of exposure to $0.5 \%$ carvacrol, norovirus had $3.87 \pm 0.61 \log 10$ of titer reduction and, after 6 hours, the reduction was $4.54 \pm 0.05 \log 10$.

Nevertheless, the antiviral activity of oregano in facile preparations, such as infusion and decoction, becomes evident. Although it demands further studies and application of others and more sophisticated methodologies, the hydroalcoholic extract (which is not very difficult to prepare) showed promising potential. In this regard, it is important to continue the research involving oregano preparations, such as the ones presented in our study, as an aid to conventional treatments. Our results demonstrate the potential for the use of both three extracts, since the concentration of $2 \mathrm{mg} / \mathrm{mL}$ for infusion, and the concentration of $1 \mathrm{mg} / \mathrm{mL}$ for both decoction and hydroalcoholic extract showed a significant reduction of the viral titer while maintaining the cell viability. Additionally, the virucidal activity assays point to the use of oregano extracts presented here as an alternative to prevent infections by disinfecting environments and fomites.

\section{Conclusion}

This study demonstrated the promising therapeutic usefulness of the polar extracts of $O$. vulgare in the control of bovine infectious rhinotracheitis, caused by BoHV-1. Among the evaluated extracts, the infusion at $2 \mathrm{mg} / \mathrm{ml}$ as pre-treatment was highlighted by the total viral inhibition in addition to the maintenance of cell viability in more than $80 \%$.

Although homemade preparations of oregano are widely and safely used for culinary purposes around the world, they should be used with caution for in vivo therapeutic purposes, as further studies still needs to be performed to unravel their molecular mechanism and effectiveness in viral infections and stablish therapeutical doses. In addition, future studies should evaluate the antiviral and virucidal action of $O$. vulgare extracts on other DNA viruses and also on RNA viruses, and on nonenveloped and enveloped virus, expanding their spectrum of use.

\section{References}

Agiomyrgianaki, A. \& Dais, P. (2012). Simultaneous determination of phenolic compounds and triterpenic acids in oregano growing wild in Greece by 31PNMR spectroscopy. Magnetic Resonance in Chemistry, 50 (11), 739-748.

Al-Jaboury, T. M. A. (2015). Effect of crude extract of Origanum vulgare on the inhibition of some pathogenic bacteria and causing spoilage of food. AlAnbar Journal of veterinary sciences, 8 (2), 28-33.

Araújo, D. L., Machado, B. A. S., Mascarenhas, J. M. F., Alves, S. P., Sousa, S. L. F., Moura, L. C., Melo, B. C., Luz, T. E. M, Loures, L. L. S., Apolinário, J. M. S. S, Sousa, T. O., Siqueira, L. C., Moura, M. A. S., Rocha, L. R. \& Souza, M. S. (2021). Analysis of the antimicrobial activity of the essential oil of oregano (Origanum vulgare): a review study on the main effects on pathogens. Research, Society and Development, 10 (2), e36810212584.

Astani, A., Reichling, J. \& Schnitzler, P. (2011). Screening for Antiviral Activities of Isolated Compounds from Essential Oils. Evidence-based Complementary and Alternative Medicine, 2011. 
Baser, K. H. C. (2002). The Turkish Origanum species. In: Kintzios, S. E. Oregano: the genera Origanum and Lippia. Taylor and Francis.

Bastos, E. M. A. F., Galbiati, C., Loureire, M. \& Scoaris, D. O. (2011). Indicadores físico-químicos e atividade antibacteriana de própolis marrom frente à Escherichia coli. [Physical-chemical indicators and antibacterial activity of brown propolis against Escherichia coli]. Arquivo Brasileiro de Medicina Veterinária e Zootecnia, 63 (5), 1255-1259.

Bekut, M., Brkić, S., Kladar, N., Dragović, G., Gavarić, N. \& Božin, B. (2018). Potential of selected Lamiaceae plants in anti(retro)viral therapy. Pharmacological Research (in press), 133, 301-314.

Blank, D. E., Alves, G. H., Freitag, R. A., Corrêa, R. A., Hübner, S. O. \& Cleff, M. B. (2016). Composição química e citotoxicidade de Origanum vulgare L. e Rosmarinus officinalis L. Science and Animal Health, 4 (2), 117-130.

Blank, D. E., Corrêa, R. A., Freitag, R. A, Cleff, M. B. \& Hübner, S. O. (2017). Anti-equine arteritis vírus of ethanolic extract and compounds from Origanum vulgare. Semina: Ciências Agrárias, 38 (2), 759-764.

Blank, D. E., Hübner, S. O., Alves, G. H., Cardoso, C. A. L., Freitag, R. A. \& Cleff, M. B. (2019). Chemical Composition and Antiviral Effect of Extracts of Origanum vulgare. Advances in Bioscience and Biotechnology, 10, 188-196.

Brondani, L. P., Silva Neto, T. A., Freitag, R. A. \& Lund, R. G. (2018). Evaluation of anti-enzyme properties of Origanum vulgare essential oil against oral Candida albicans. Journal of Medical Mycology, 28 (1), 30341-30344.

Burt, S. (2006). Essential oils: their antibacterial properties and potential applications in foods - a review. International Journal of Food Microbiology, 94 (3), $223-253$.

Carezzano, M. E., Sotelo, J. P, Primo, E., Reinoso, E. B., Palettirovey, M. F., Demo, M. S, Giordano, W. F. \& Oliva, M. L. M. (2017). Inhibitory effect of Thymus vulgaris and Origanum vulgare essential oils on virulence factors of phytopathogenic Pseudomonas syringae strains. Plant Biology, 19 (4), $599-607$.

Castro, L. L. D., Madrid, I. M., Aguiar, C. L. G., Castro, L. M., Cleff, M. B., Berne, M. E. A. \& Leite, F. P. L. (2013). Origanum vulgare (Lamiaceae) ovicidal potential on gastrointestinal nematodes of cattle. Ciência Animal Brasileira, 14 (4), 508-513.

Coccimiglio, J., Alipour, M., Jiang, Z., Gottardo, C. \& Suntres, Z. (2016). Antioxidant, Antibacterial, and Cytotoxic Activities of the Ethanolic Origanum vulgare Extract and Its Major Constituents. Oxidative Medicine and Cellular Longevity, 2016, 1-8.

Costa, A. C., Santos, B. H. C., Santos Filho, L. \& Lima, E. O. (2009). Antibacterial activity of the essential oil of Origanum vulgare L. (Lamiaceae) against bacterial multiresistant strains isolated from nosocomial patients. Revista Brasileira de Farmacognosia, 19 (1B), $236-241$.

EFSA: European Food Safety Authority Journal. (2010). Scientific opinion on the use of oregano and lemon balm extracts as a food.

Elizaquível, P., Azizkhani, M., Aznar, R. \& Sanchez, G. (2013). The effect of essential oils on norovirus surrogates. Food Control, 32 (1), $275-278$.

FDA: Food and Drug Administration 2017. USA: U. S. Food and Drug Administration. https://www.accessdata.fda.gov/scripts/cdrh/cfdoc s/cfcfr/CFRSearch.cfm?fr=182.10

Franco, A.C. \& Roeche, P. M. (2007). Herpesviridae. In: Flores, E. F. Virologia Veterinária. Editora UFMS

Gerothanassis, I. P., Exarchou, V., Lagouri, V., Troganis, A., Tsimidou, M. \& Boskou, D. (1998). Methodology for identification of phenolic acids in complex phenolic mixtures by high-resolution two-dimensional nuclear magnetic resonance. Application to methanolic extracts of two Oregano species. Journal of Agricultural and Food Chemistry, 46 (10), 4185-4192.

Gilling, D. H., Kitajima, M., Torrey, J. R. \& Bright, K. R. (2014). Antiviral efficacy and mechanisms of action of oregano essential oil and its primary component carvacrol against murine norovirus. Journal of Applied Microbiology, 116 (5), 1149-1163.

Grevsen, K., Frette, X. C. \& Christensen, L. P. (2009). Content and composition of volatile terpenes, flavonoids and phenolic acids in Greek oregano (Origanum vulgare L. ssp. hirtum) at different development stages during cultivation in cool temperate climate. European Journal of Horticultural Science, 74 (5), 193-203.

Hage, J. J., Schukken, Y. H., Barkema, H. W., Benedictus, G., Rijsewijk, F. A. \& Wentink, G. H. (1996). Population dynamics of bovine herpesvirus 1 infection in a dairy herd. Veterinary Microbiology, 53 (1-2), 169-180.

Hossain, M. B., Rai, D. K., Brunton, N. P., Martin-Diana, A. B. \& Barry-Ryan, C. (2010). Characterization of phenolic composition in Lamiaceae spices by LC-ESI-MS/MS. Journal of Agricultural and Food Chemistry, 58 (19), 10576-10581.

Kalemba, D. \& Kunicka, A. (2003). Antibacterial and antifungal properties of essential oils. Current Medicinal Chemistry, 10 (10), $813-829$.

Kandasamy, M., Nasimuddin, S., Gnanadesikan, S., Nithya, J. \& Vennimalai, S. (2017). Antibacterial activity of aqueous infusion and decoction of dried leaves of oregano (Origanum vulgare) on clinical bacterial isolates. Indian Journal of Microbiology Research, 4 (4), $442-447$.

Kaul, T. N., Middleton, E. \& Ogra, P. L. (1985). Antiviral effect of flavonoids on human virus. Journal of Medical Virology, 15 (1), $71-79$.

Kintzios, S. E. (2002). Profileof the multifaceted prince of the herbs. In: Kintzios, S. E. Oregano: the genera Origanum and Lippia. London: Taylor and Francis.

Koch, C., Reichling, J., Schneele, J. \& Schnitzler, P. (2008). Inhibitory effect of essential oils against herpes simplex vírus type 2. Phytomedicine, 15 (1-2), 71 78. 
Kosová, M., Hhrádková, I., Mátlová, V., Kadlec, D., Šmidrkal, J. \& Filip, V. (2015). Antimicrobial effect of 4-hydroxybenzoic acid Ester with glycerol. Journal of Clinical Pharmacy and Therapeutics, 40 (4), 436-440.

Ksouri, S., Djebir, S., Bentorki, A. A., Gouri, A., Hadef, Y. \& Benakhla, A. (2017). Antifungal activity of essential oils ex tract from Origanum floribundum Munby, Rosmarinus officinalis L. and Thymus ciliatus Desf. against Candida albicans isolated from bovine clinical mastitis. Journal of Medical Mycology, 27 (2), 245-249.

Loi, I., Thiry, J., Attili, A., Preziuso, S. \& Cuteri, V. (2013). Control Strategies for Infectious Bovine Rhinotracheitis (IBR) in Italy. XX International Congress of Mediterranean Federation of Health and Production of Ruminants, 19-22.

Longe, J. L. (2005).The Gale encyclopedia of alternative medicine. (2nd ed.), Thomson Gale.

Martins, N., Barros, L., Santos-Buelga, C., Henriques, M., Silva, S. \& Ferreira, I. C. F. R. (2014). Decoction, infusion and hydroalcoholic extract of Origanum vulgare L.: Different performances regarding bioactivity and phenolic compounds. Food Chemistry, 158, 73-80.

Miron, T. L., Plaza, M., Bahrim, G., Ibañez, E. \& Herrero, M. (2011). Chemical composition of bioactive pressurized extracts of Romanian aromatic plants. Journal of Chromatography A, 1218 (30), 4918-4927.

Mosmann, T. (1983). Rapid colorimetric assay for cellular growth and survival application to proliferation and cytotoxicity assays. Journal of Immunological Methods, 65 (1-2), 55-63.

Orhan, I. E., Ozcelik, B., Kartal, M. \& Kan, Y. (2012). Antimicrobial and antiviral effects of essential oils from selected Umbelliferae and Labiatae plants and individual essential oil components. Turkish Journal of Biology, 36 (3), 239-246.

Palmeira de Oliveira, A., Salgueiro, L., Palmeira de Oliveira, R., Martinez de Oliveira, J., Pin-Vaz, C., Queiroz, J. A. \& Rodrigues, A. G. (2009). AntiCandida activity of essential oils. Mini-Reviews in Medicinal Chemistry, 9 (11), 1292-1305.

Pauli, A. (2006). Anticandidal low molecular compounds from higher plants with special reference to compounds from essential oils. Medicinal Research Reviews, 26 (2), 223-268.

Pereira, A. S., Shitsuka, D. M., Parreira, F. J. \& Shitsuka, R. (2018). Metodologia da pesquisa científica. UFSM.

Pereira, M. M. A., Morais, L. C., Zeneratto, N. J., Reis, W. S. M., Gómez, O. C., Luiz, J. H. H., Moreira, D. M. B., Pasqual, M. \& Dória, J. (2020). Organic management vs. conventional management influence the antimicrobial activity of essential oils of Origanum vulgare L. Research, Society and Development, 9 (11), e4239118504.

Reed, R. H. \& Muench, H. (1938). A simple method of estimating fifty percent end points. American Journal of Epidemiology, 27 (3), $493-497$.

Rodriguez-Meizoso, I., Marin, F. R., Herrero, M., Senorans, F. J., Reglero, G., Cifuentes, A. \& Ibañes, E. (2006). Subcritical water ex traction of nutraceuticals with antioxidant activity from oregano: Chemical and functional characterization. Journal of Pharmaceutical and Biomedical Analysis, 41 (5), $1560-1565$.

Roizman, B. \& Pellett, P. E. (2013). Herpesviridae. In: Knipe, D. M. \& Howley, P. M. Fields Virology. (6th ed.), Philadelphia: Lippincott Williams \& Wilkins publishers.

Santos, J. R. N., Teles, A. M., Ferreira, C. G. \& Mouchrek, A. N. (2020). Avaliação da atividade bactericida e antioxidante do óleo essencial e do extrato hidroalcoólico de orégano (Origanum vulgare). Research, Society and Development, 9 (10), e7829108410.

Siddiqui, Y. M., Ettayebi, M., Haddad, A. M. \& Al-Ahdal, M. N. (1996). Effect of essential oils on the enveloped viruses: antiviral activity of oregano and clove oils on herpes simplex vírus type 1 and Newcastle disease virus. Medical Science Research, 24, 185-186.

Shen, D., Pan, M. H., Wu, Q. L., Park, C. H., Juliani, H. R., Ho, C. T. \& Simon, J. E. (2010). LC-MS Method for the simultaneous quantitation of the antiinflammatory constituents in oregano (Origanum species). Journal of Agricultural and Food Chemistry, 58 (12), 7119-7125.

Skoula, M., Grayer, R. J., Kite, G. C. \& Veitch, N. C. (2008). Exudate flavones and flavanones in Origanum species and their interspecific variation. Biochemical Systematics and Ecology, 36 (8), 646-654.

Szczepanik, M., Walczak, M., Zawitowska, B., Michalska-Sionkowska, M., Szumny, A., Wawrzeńczyk, C. \& Brzezinska, M. S. (2018). Chemical composition, antimicromicrobial activity and insecticidal activity against the lesser mealworm Alphitobiusdiaperinus (Panzer) (Coleoptera: Tenebrionidae) of Origanum vulgare L. ssp. hirtum (Link) and Artemisia dracunculus L. essential oils. Journal of the Science of Food and Agriculture, 98 (2), 767-774.

Thakur, N., Qureshi, A. \& Kumar, M. (2012). AVPpred: collection and prediction of highly effective antiviral peptides. Nucleic Acids Research, 40 (1), 199 204.

Vanaclocha, B., García, A. A. \& Salazar, J. I. G. (2003). Fitoterapia: Vademecum de Prescripcion. (4th ed.), Elsevier.

Waller, S. B., Hoffmann, J. F., Madrid, I. M., Picoli, T., Cleff, M. B., Chaves, F. C., Zanette, R. A., Mello, J. R. B., de Faria, R. O. \& Meireles, M. C. A. (2018). Polar Origanum vulgare (Lamiaceae) extracts with antifungal potential against Sporothrix brasiliensis. Medical Mycology, 56 (2), $225-233$.

Waller, S. B., Madrid, I. M., Silva, A. L., Dias de Castro, L. L., Cleff, M. B., Ferraz, V., Meireles, M. C. A., Zanette, R. \& de Mello, J. R. (2016). In Vitro Susceptibility of Sporothrix brasiliensis to Essential Oils of Lamiaceae Family. Mycopathologia, 181 (11-12), 857-863.

Wijesundara, N. M. \& Rupasinghe, H. P. V. (2018). Essential oils from Origanum vulgare and Salvia officinalis exhibit antibacterial and anti-biofilm activities against Streptococcus pyogenes. Microbial Pathogenesis, 117, 118-127.

Zhang, X. L., Guo, Y. S., Wang, C. H., Li, G. Q., Xu, J. J., Chung, H. Y., Ye, W. C., Li, Y. L. \& Wang, G. C. (2014). Phenolic compounds from Origanum vulgare and their antioxidant and antiviral activities. Food Chemistry, 152 (1), 300-306. 